\title{
Pengetahuan, Sikap, dan Perilaku Responden Mengenai ASI Eksklusif di Desa Ciburial, Kecamatan Cimenyan, Kabupaten Bandung
}

Knowledge, Attitude, and Behavior of Respondents Regarding Exclusive Breast Feeding in Desa Ciburial, Kecamatan Cimenyan, Kabupaten Bandung

\author{
Franky S Supriady ${ }^{1}$, Diana K Jasaputra ${ }^{2 *}$, Stella T Hasianna ${ }^{3}$, July Ivone ${ }^{4}$ \\ ${ }^{1}$ Bagian Ilmu Kesehatan Anak, Fakultas Kedokteran, Universitas Kristen Maranatha \\ ${ }^{2}$ Bagian Farmakologi, Fakultas Kedokteran, Universitas Kristen Maranatha \\ ${ }^{3}$ Bagian Ilmu Faal, Fakultas Kedokteran, Universitas Kristen Maranatha \\ ${ }^{4}$ Bagian Ilmu Kesehatan Masyarakat, Fakultas Kedokteran, Universitas Kristen \\ Maranatha \\ Jl Prof. drg. Surya Sumantri MPH No.65 Bandung 40164 Jawa Barat Indonesia \\ *Penulis korepondensi \\ Email: dianakjasaputra67@gmail.com
}

Received: December 25, 2020

Accepted: August 7, 2021

\begin{abstract}
Abstrak
Pemberian ASI dapat menurunkan risiko diare, infeksi saluran napas, mencegah munculnya alergi pada bayi, serta menurunkan risiko kanker payudara dan penyakit metabolik pada ibu. Beberapa hal dapat menyebabkan seorang ibu tidak memberikan ASI kepada bayinya. Pengetahuan yang dimiliki oleh seorang ibu akan sangat berpengaruh pada sikap dan perilakunya, dalam hal ini pemberian ASI Eksklusif oleh ibu kepada bayinya. Tujuan penelitian ini adalah untuk mengetahui pengetahuan, sikap, dan perilaku responden terhadap pemberian ASI Eksklusif di Desa Ciburial, Kecamatan Cimenyan, Kabupaten Bandung. Instrumen yang digunakan adalah kuesioner untuk mengetahui pengetahuan, sikap, dan perilaku mengenai ASI Eksklusif. Responden yang menjawab kuesioner tersebut adalah responden di Desa Ciburial, Kecamatan Cimenyan, Kabupaten Bandung dengan kriteria inklusi responden yang mengisi kuisioner dengan lengkap. Penelitian ini dilaksanakan antara bulan Januari hingga Desember 2020 sejak persiapan hingga penyusunan hasil penelitian. Simpulan penelitian ini adalah pengetahuan responden mengenai ASI Eksklusif sudah cukup baik, namun belum semua / belum 100\% responden yang memahami dan memiliki sikap serta memiliki perilaku memberikan ASI Eksklusif pada bayinya.
\end{abstract}

Kata kunci: ASI Eksklusif, pengetahuan, sikap, perilaku

\begin{abstract}
Breast milk has benefits for both the baby and the mother, therefore breastfeeding is very important. Several things may cause a mother not to give her breast milk to her baby, including the knowledge that a mother has will greatly affect her attitude and behavior, in this case exclusive breastfeeding by the mother for her baby. The purpose of this study was to determine the knowledge, attitudes, and behavior of respondents towards exclusive breastfeeding. The instrument used was a questionnaire to determine knowledge, attitudes, and behavior regarding exclusive breastfeeding. Respondents who answered the questionnaire were young mothers in the Desa Ciburial, Kecamatan Cimenyan, Kabupaten Bandung. This research was carried out from preparation to compiling research results in January 2020-December 2020. In conclusion, the
\end{abstract}




\section{Research Article}

knowledge of respondents about exclusive breastfeeding is good enough, but it turns out that not all / not 100\% of the respondents understand and have the attitude and behavior to give exclusive breastfeeding to their babies.

Keywords: Exclusive breastfeeding, knowledge, attitudes; behavior

\section{Pendahuluan}

Air Susu Ibu (ASI) adalah makanan terbaik untuk bayi. Pemberian ASI eksklusif selama 6 bulan pertama kehidupan seorang bayi memiliki banyak manfaat. Manfaat pemberian ASI bagi bayi antara lain melindungi tubuh bayi dari kuman penyakit, meningkatkan kecerdasan intelektual atau Intelligence Quotient (IQ) bayi, melatih perkembangan rahang, jantung paru-paru, menurunkan risiko infeksi saluran napas, infeksi telinga, dan diare, meningkatkan kecerdasan emosional atau Emotional Quotient (EQ) bayi, serta menurunkan risiko terkena alergi dan kanker pada anak. Manfaat menyusui bagi ibu antara lain ibu menjadi lebih sehat dengan menurunkan risiko kanker payudara, kanker, ovarium, penyakit jantung dan metabolik, serta osteoporosis. Pemberian ASI kepada bayinya akan meningkatkan ikatan batin ibu dengan bayinya. Selain itu, pemberian ASI juga memberikan keuntungan pada ekonomi keluarga, dalam hal pengeluaran biaya kesehatan rendah. Ibu bekerja yang menyusui bayinya menjadi lebih sehat, dan lebih jarang absen bekerja, produktivitas kerja meningkat, Happiness index meningkat, dan risiko gangguan psikiatrik sangat menurun. ${ }^{1-2}$ Berdasarkan hasil Riskesdas 2018 proporsi pola pemberian ASI pada bayi umur 0-5 bulan di Indonesia sebanyak 37,3\% ASI ekslusif, 9,3\% ASI parsial, dan 3,3\% ASI predominan. Berdasarkan daerah tempat tinggal, hasil Susenas Maret 2017 menunjukkan bahwa persentase status Inisiasi Menyusui Dini (IMD) di daerah perkotaan $(70,02 \%)$ lebih tinggi dibandingkan perdesaan $(64,05 \%)$. Berdasarkan provinsi, persentase tertinggi bayi baru lahir mendapat IMD tahun 2017 adalah Provinsi Aceh (97,31\%), sedangkan persentase terendah adalah Provinsi Papua (15\%)..$^{3-4}$

Secara fisiologis, hormon yang mengontrol produksi ASI secara langsung adalah prolaktin dan oksitosin. Hormon estrogen juga berpengaruh secara tidak langsung terhadap produksi ASI. Sedotan bayi pada puting payudara ibu merupakan rangsangan sensorik yang dihantarkan ke otak. Lobus anterior hipofisis akan menyekresikan prolaktin dan hipofisis posterior menyekresikan oksitosin. Kadar prolaktin yang meningkat dalam darah akibat rangsangan sedotan bayi akan menstimulasi produksi ASI oleh alveoli. Oksitosin membuat selsel mioepitelial sekitar alveoli berkontraksi, sehingga ASI yang berada di dalam alveoli keluar ke duktus-duktus. Prolaktin seperti yang telah disebutkan sebelumnya merupakan salah satu hormon 


\section{Research Article}

yang memengaruhi produksi ASI. Peningkatan kadar prolaktin secara otomatis akan meningkatkan produksi ASI. Pemberian ASI Eksklusif merupakan pola nutrisi yang paling baik untuk bayi berumur 0-6 bulan

Seperti telah disebutkan sebelumnya, ASI merupakan makanan terbaik bahkan dapat dikatakan sebagai makanan sempurna untuk bayi. Komposisi ASI yang disekresikan oleh kelenjar susu tidak selalu sama. Hasil sekresi kelenjar susu yang pertama kali dikeluarkan disebut kolostrum. Kualitas ASI yang disekresikan kelenjar susu bergantung dari gizi makanan, status imunologi, kondisi psikologis, dan status sosial ekonomi dari ibu. Bayi yang disusui ibunya akan menjadi bayi yang sehat, hal ini terbukti baik di negara maju ataupun di negara berkembang. Pemberian ASI kepada bayi mempunyai efek mencegah infeksi, kelebihan berat badan, obesitas, diabetes, dan mencegah keganasan pada bayi. Bayi yang mendapat ASI, perkembangan sarafnya akan menjadi baik, juga mengurangi risiko enterokolitis nekrotikans. ${ }^{5}$

Pemberian ASI eksklusif sering mengalami kegagalan walaupun ASI merupakan makanan terbaik untuk bayi. Beberapa hal dapat menyebabkan kegagalan program ASI eksklusif di Indonesia. Faktor-faktor yang menyebabkan masalah kegagalan ini antara lain terkait dengan pengetahuan, pendidikan dan pekerjaan ibu. ${ }^{6}$ Pemberian ASI Eksklusif adalah pemberian ASI saja pada bayi sejak bayi lahir hingga usia 6 bulan. Menurut penelitian, pemberian ASI eksklusif dapat dipengaruhi oleh penyuluhan media sosial mengenai ASI eksklusif, dukungan petugas kesehatan, dan pengalaman menyusui sebelumnya. ${ }^{7}$

Ilmu pengetahuan dan penelitian menunjukkan bahwa ASI memiliki manfaat baik untuk bayi dan ibunya, oleh karena itu pemberian ASI sangat penting. Faktor penyebab seorang ibu tidak memberikan ASI kepada bayinya, seperti pengetahuan yang dimiliki ibu akan sangat berpengaruh terhadap sikap dan perilaku pemberian ASI Eksklusif oleh ibu kepada bayinya. Tujuan penelitian ini adalah untuk mengetahui pengetahuan, sikap dan perilaku ibu-ibu muda terhadap pemberian ASI Eksklusif di Desa Ciburial, Kecamatan Cimenyan, Kabupaten Bandung.

\section{Metode}

Penelitian ini merupakan penelitian deskriptif yang kemudian dilakukan analisis. Penelitian ini telah disetujui oleh Komite Etik Penelitian Fakultas Kedokteran Universitas Kristen Maranatha dengan nomor 1504/EP/X/2020 serta sudah mendapatkan ijin pada pihak berwenang di daerah tersebut. Instrumen yang digunakan adalah kuesioner yang sudah divalidasi sebelumnya untuk mengetahui pengetahuan, sikap, dan perilaku mengenai ASI Eksklusif. Kriteria inklusi: ibu 


\section{Research Article}

berusia di atas 18 tahun, bersedia mengisi kuesioner, sedangkan kriteria eksklusi adalah kuesioner yang tidak lengkap. Penelitian dilakukan pada responden yang hadir saat penyuluhan ASI yang dilaksanakan di Desa Ciburial Kecamatan Cimenyan Kabupaten Bandung. Responden yang hadir diberi kuesioner dalam bentuk fisik sebelum dan sesudah pelaksanaan. Setelah penyuluhan dilaksanakan, responden diminta untuk mengisi kuesioner sekali lagi, untuk mengetahui dampak positif setelah penyuluhan. Kegiatan penyuluhan ini juga diikuti oleh peserta / responden yang berada di Cileuyi, Bogor, Cirebon, Sanggau Kalimantan Barat, Balikpapan, Kudus, Surabaya, Subang, dan Jepara secara daring. Responden yang berada di berbagai tempat tersebut juga mendapat link kuesioner yang diisi sebelum dan sesudah penyuluhan mengenai ASI secara daring. Penelitian ini dilaksanakan antara bulan Januari-Desember 2020 mulai persiapan hingga penyusunan hasil penelitian.

Pertanyaan terkait pengetahuan ibu terdiri atas 10 pertanyaan, dengan setiap jawaban benar diberi nilai 5 untuk setiap pertanyaan, pertanyaan terkait sikap ibu terdiri atas 5 pertanyaan, dengan setiap jawaban benar diberi nilai 5 , pertanyaan terkait perilaku ibu terdiri atas 5 pertanyaan, dengan setiap jawaban benar diberi nilai 5. Pertanyaan mengenai pengetahuan yang berjumlah 10 pertanyaan apabila dijawab semua benar dan berarti skor yang diperoleh adalah 50 dan dikategorikan pengetahuan baik, sedangkan responden yang menjawab benar pertanyaan mengenai pengetahuan kurang dari 10 pertanyaan atau skor $\leq 45$, dikategorikan pengetahuan tidak baik. Pertanyaan mengenai sikap yang berjumlah 5 pertanyaan, bila dijawab semua benar, berarti skor totalnya 25 dan dikategorikan sikap baik, sedangkan responden yang menjawab benar pertanyaan mengenai sikap kurang dari 5 pertanyaan atau skor $\leq 20$, dikategorikan sikap tidak baik. Pertanyaan mengenai perilaku yang berjumlah 5 pertanyaan, bila dijawab semua benar, berarti skor totalnya 25 dan dikategorikan perilaku baik, sedangkan responden yang menjawab benar pertanyaan mengenai perilaku kurang dari 5 pertanyaan atau skor $\leq 20$, dikategorikan perilaku tidak baik. Data hasil akan dianalisis menggunakan uji McNemar untuk menilai pengaruh penyuluhan terhadap pengetahuan responden. Hipotesis statistiknya adalah H0: tidak terdapat perubahan pengetahuan responden sebelum dan sesudah penyuluhan mengenai ASI. H1: terdapat perubahan pengetahuan responden sebelum dan sesudah penyuluhan mengenai ASI. 


\section{Research Article}

\section{Hasil}

Penyuluhan dilaksanakan secara daring diikuti oleh responden yang berada di Desa Ciburial Kecamatan Cimenyan Kabupaten Bandung dan juga diikuti oleh responden yang berada di beberapa daerah, seperti Cileunyi, Bogor, Cirebon, Sanggau Kalimantan Barat, Balikpapan, Kudus, Surabaya, Subang, dan Jepara.

Responden yang ikut serta dalam penelitian ini berjumlah 36 orang, dengan jenis kelamin wanita 30 orang dan pria 6 orang, rentang usia yang menjawab kuesioner ini adalah antara 19 50 tahun, dengan 18 orang responden berusia 19-25 tahun, 4 orang berusia 26-35 tahun, 11 orang berusia 36-45 tahun, dan 3 orang berusia 46-50 tahun. Responden yang berpendidikan S1 ada 18 orang, SMA 15 orang, SMP 1 orang, SD 1 orang, dan satu orang lagi tidak menyebutkan pendidikannya. Jumlah kader kesehatan yang ikut serta dalam penelitian ini berjumlah 11 orang. Jawaban responden mengenai pengetahuan ASI Eksklusif disajikan pada tabel 1. Gambar 1 menunjukkan diagram batang dari persentase responden yang menjawab benar sebelum dan sesudah penyuluhan.

\section{Tabel 1 Jawaban Responden Tentang Pengetahuan Tekait ASI Eksklusif Sebelum dan Sesudah Penyuluhan}

\begin{tabular}{llll}
\hline No & \multicolumn{1}{c}{ Pertanyaan } & $\begin{array}{l}\text { Responden yang } \\
\text { menjawab benar } \\
\text { sebelum penyuluhan }\end{array}$ & $\begin{array}{l}\text { Responden yang } \\
\text { menjawab benar } \\
\text { sesudah penyuluhan }\end{array}$ \\
\hline 1 & $\begin{array}{l}\text { Air susu ibu (ASI) dapat menurunkan risiko } \\
\text { bayi terkena diare }\end{array}$ & $91,7 \%$ & $100 \%$ \\
2 & $\begin{array}{l}\text { Menyusui dapat menurunkan risiko ibu } \\
\text { terkena kanker payudara }\end{array}$ & $100 \%$ & $100 \%$ \\
3 & $\begin{array}{l}\text { Ibu bekerja yang menyusui lebih sering absen } \\
\text { dan tidak produktif dalam bekerja }\end{array}$ & $81 \%$ & $83,3 \%$ \\
4 & $\begin{array}{l}\text { Inisiasi Menyusu Dini (IMD) sangat } \\
\text { menentukan keberhasilan menyusui }\end{array}$ & $97 \%$ & $100 \%$ \\
5 & $\begin{array}{l}\text { ASI akan tetap banyak walau jarang disusukan } \\
\text { ke bayi }\end{array}$ & $86,1 \%$ & $80 \%$ \\
6 & $\begin{array}{l}\text { Dukungan keluarga mempengaruhi } \\
\text { keberhasilan menyusui }\end{array}$ & $100 \%$ & $77 \%$ \\
7 & $\begin{array}{l}\text { Makanan yang ibu konsumsi tidak } \\
\text { mempengaruhi kualitas ASI }\end{array}$ & $94 \%$ & $93,3 \%$ \\
8 & $\begin{array}{l}\text { Bayi diberi ASI eksklusif sampai usia 6 bulan } \\
\text { ASI disebut cukup jika bayi dapat tidur } \\
\text { berjam-jam dan tidak rewel }\end{array}$ & $91,7 \%$ & $66,6 \%$ \\
10 & $\begin{array}{l}\text { Jika bayi menangis setelah menyusu } \\
\text { menandakan ASI ibu sedikit }\end{array}$ & $56 \%$ & $46,7 \%$ \\
\hline
\end{tabular}




\section{Research Article}

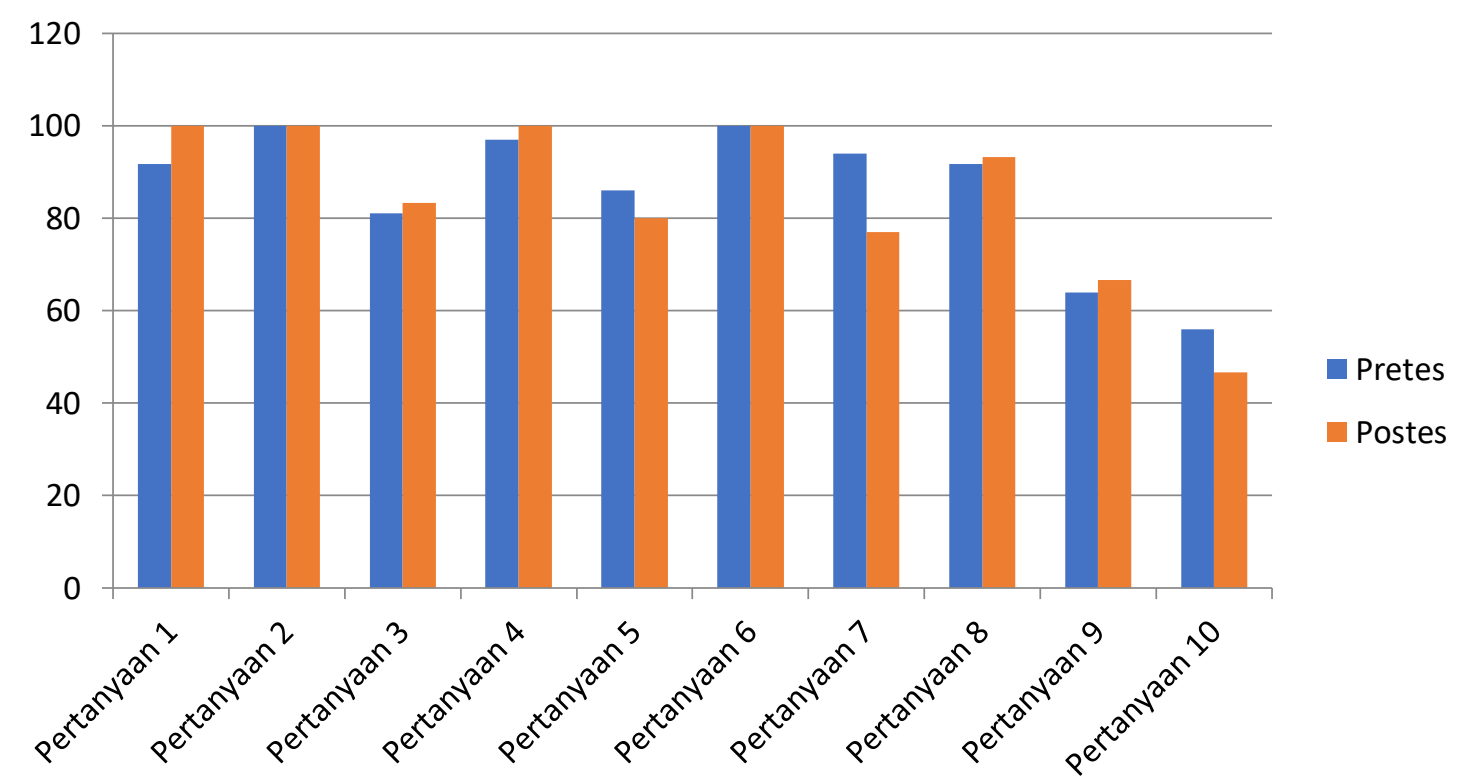

Gambar 1 Diagram Batang Persentasi Jawaban Benar Responden Masing-Masing Pertanyaan Terkait Pengetahuan Sebelum dan Sesudah Penyuluhan

Jawaban responden mengenai sikap ibu tentang ASI Eksklusif disajikan pada tabel 2.

Gambar 2 menunjukkan diagram batang dari persentase jawaban benar mengenai sikap responden sebelum dan sesudah penyuluhan mengenai ASI.

Tabel 2 Jawaban Responden Tentang Sikap Terkait ASI Eksklusif Sebelum dan Sesudah Penyuluhan

\begin{tabular}{llll}
\hline No & \multicolumn{1}{c}{ Pertanyaan } & $\begin{array}{l}\text { Responden yang } \\
\text { menjawab benar } \\
\text { sebelum } \\
\text { penyuluhan }\end{array}$ & $\begin{array}{l}\text { Responden yang } \\
\text { menjawab benar } \\
\text { sesudah penyuluhan }\end{array}$ \\
\hline $1 \quad$ & $\begin{array}{l}\text { Ibu yakin ASI akan membuat bayi Ibu cerdas dan } \\
\text { sehat }\end{array}$ & $100 \%$ & $100 \%$ \\
2 & $\begin{array}{l}\text { Menurut Ibu, susu formula penting sebagai } \\
\text { tambahan ASI agar bayi cerdas }\end{array}$ & $70 \%$ \\
$3 \quad \begin{array}{l}\text { Ibu siap memberikan ASI saja kepada bayi } \\
\text { sampai usia 6 bulan }\end{array}$ & $100 \%$ & $100 \%$ \\
\hline $\begin{array}{l}\text { Ibu merasa perlu mengonsumsi makanan bergizi } \\
\text { setiap hari agar ASI ibu berkualitas }\end{array}$ & $100 \%$ & $100 \%$ \\
\hline $\begin{array}{l}\text { Jika ibu merasa ASI ibu tidak lancar, ibu akan } \\
\text { berkonsultasi ke tenaga kesehatan terlebih dahulu } \\
\text { sebelum memutuskan membeli susu formula }\end{array}$ & $100 \%$ & \\
\hline
\end{tabular}




\section{Research Article}

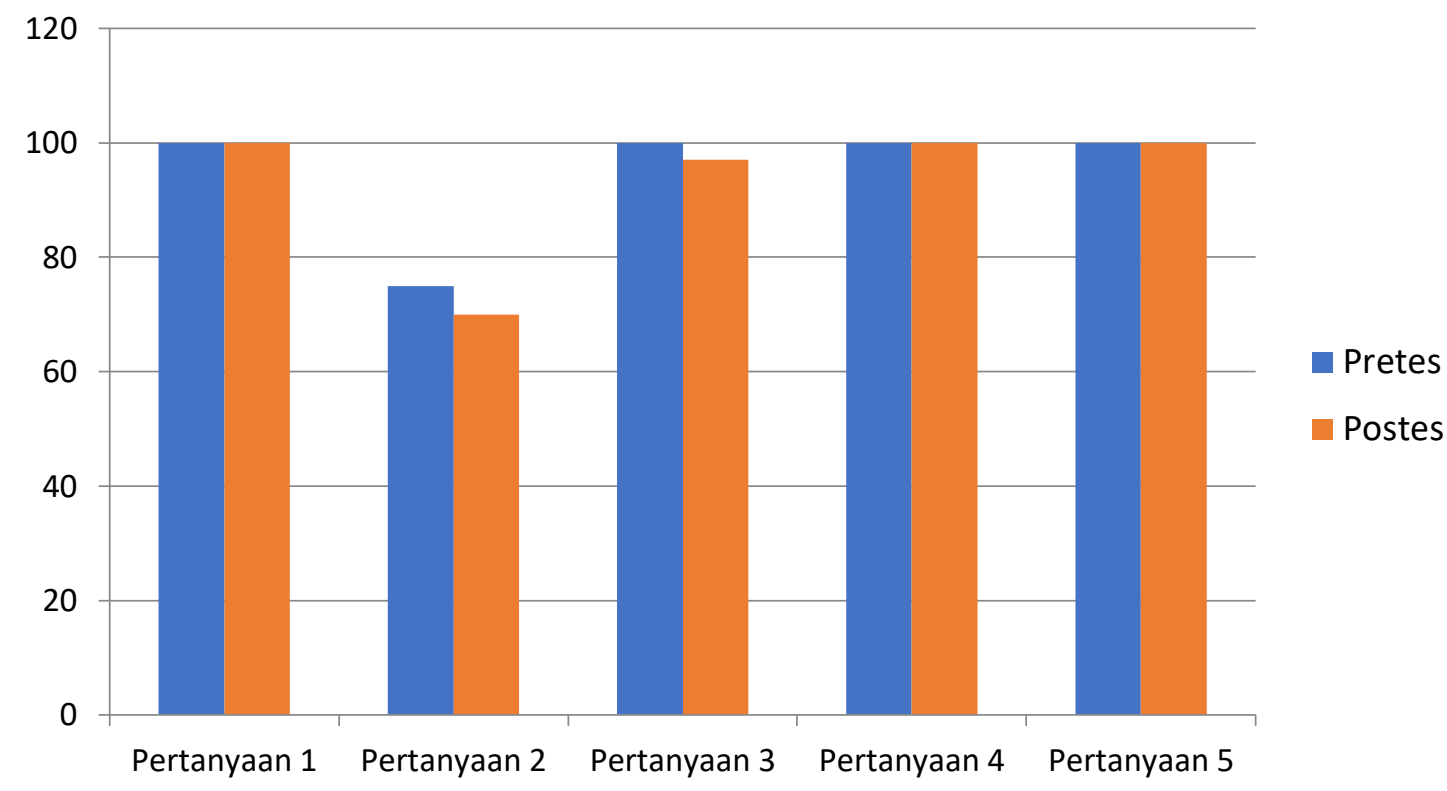

\section{Gambar 2 Diagram Batang Persentasi Jawaban Benar Responden Masing-Masing Pertanyaan Terkait Sikap Sebelum dan Sesudah Penyuluhan}

Jawaban responden mengenai perilaku ibu tentang ASI Eksklusif disajikan pada tabel 3.

Gambar 3 menunjukkan diagram batang dari persentase jawaban benar mengenai perilaku responden sebelum dan sesudah penyuluhan tentang ASI.

Tabel 3 Jawaban Responden Tentang Perilaku Terkait ASI Eksklusif Sebelum dan Sesudah Penyuluhan

\begin{tabular}{llll}
\hline No & \multicolumn{1}{c}{ Pertanyaan } & $\begin{array}{l}\text { Responden yang } \\
\text { menjawab benar } \\
\text { sebelum } \\
\text { penyuluhan }\end{array}$ & $\begin{array}{l}\text { Responden yang } \\
\text { menjawab benar } \\
\text { sesudah penyuluhan }\end{array}$ \\
\hline $1 \quad$ & $\begin{array}{l}\text { Ibu memberikan ASI saja kepada bayi sampai } \\
\text { usia 6 bulan }\end{array}$ & $92 \%$ \\
\hline $\begin{array}{l}\text { Setiap hari Ibu mengonsumsi nasi, lauk pauk, } \\
\text { sayur, buah, dan air putih dalam jumlah yang } \\
\text { cukup (3x makan utama, 2x makanan ringan) }\end{array}$ & $100 \%$ & $100 \%$ \\
\hline $\begin{array}{l}\text { Ibu menimbang berat badan bayi setiap bulan } \\
\text { untuk memantau kecukupan ASI dan } \\
\text { pertumbuhan bayi } \\
\text { Apakah ibu sering berdiskusi dengan suami dan } \\
\text { keluarga tentang keputusan ibu untuk memberi } \\
\text { ASI eksklusif kepada bayi? } \\
\text { Apakah ibu menyusui ibu >6-8 kali per hari dan } \\
\text { memastikan bayi menyusu dengan baik? }\end{array}$ & $94 \%$ & $97 \%$ \\
\hline
\end{tabular}




\section{Research Article}

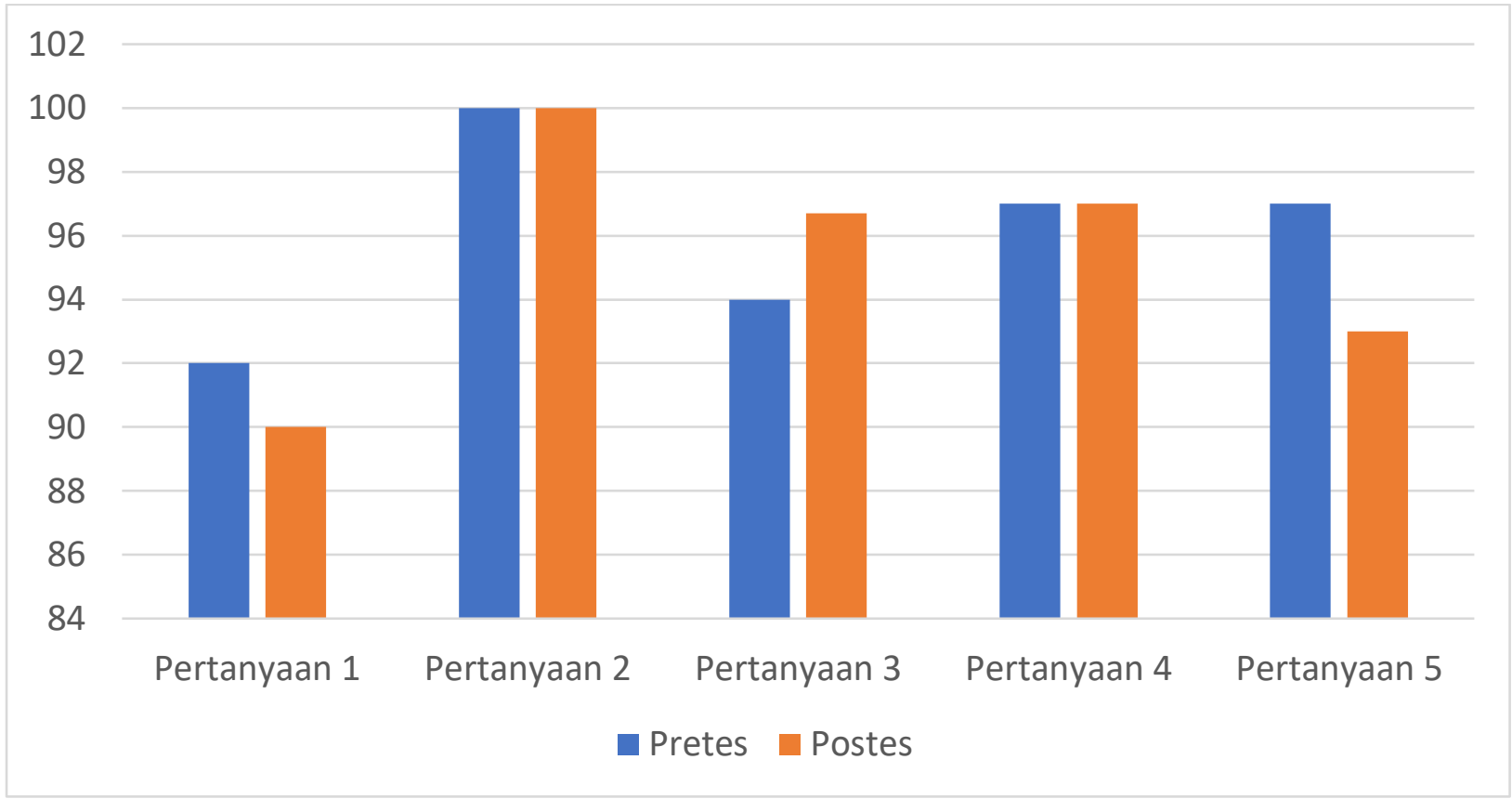

\section{Gambar 3 Diagram Batang Persentasi Jawaban Benar Responden Masing-Masing Pertanyaan Terkait Perilaku Sebelum dan Sesudah Penyuluhan}

Pengujian perbandingan pengetahuan, sikap dan perilaku responden sebelum dan sesudah penyuluhan disajikan dalam tabel 4, 5, 6. Jumlah responden yang menjawab semua pertanyaan mengenai pengetahuan mengenai ASI benar berarti memiliki pengetahuan yang baik sebelum penyuluhan maupun sesudah penyuluhan adalah 16 orang. Jumlah responden yang menjawab pertanyaan tidak semuanya benar sebelum penyuluhan dan menjadi semua benar setelah penyuluhan berjumlah 4 orang. Jumlah responden yang menjawab pertanyaan semua benar sebelum penyuluhan dan menjadi tidak semua benar setelah penyuluhan adalah 2 orang, dan jumlah responden yang menjawab pertanyaan tidak semua benar baik sebelum penyuluhan maupun sesudah penyuluhan adalah 5 orang. Hasil data dianalis menggunakan uji McNemar untuk menilai pengaruh penyuluhan terhadap pengetahuan responden. Hipotesis statistiknya adalah H0: tidak terdapat perubahan pengetahuan responden sebelum dan sesudah penyuluhan mengenai ASI. H1: terdapat perubahan pengetahuan responden sebelum dan sesudah penyuluhan mengenai ASI. 


\section{Research Article}

Tabel 4 Perbandingan Pengetahuan Responden mengenai Pemberian ASI Sebelum dan Sesudah Penyuluhan

\begin{tabular}{|c|c|c|c|c|}
\hline & \multicolumn{2}{|c|}{ Sesudah Penyuluhan } & \multirow[b]{2}{*}{ Jumlah } \\
\hline & & Pengetahuan tidak baik & Pengetahuan baik & \\
\hline \multirow{3}{*}{$\begin{array}{l}\text { Sebelum } \\
\text { Penyuluhan }\end{array}$} & $\begin{array}{l}\text { Pengetahuan } \\
\text { tidak baik }\end{array}$ & 16 & 4 & 20 \\
\hline & $\begin{array}{l}\text { Pengetahuan } \\
\text { baik }\end{array}$ & 2 & 3 & 5 \\
\hline & & 18 & 7 & 25 \\
\hline
\end{tabular}

Keterangan: Uji McNemar : X hitung $=(\mathrm{I} 4-2 \mathrm{I}-1)^{2} /(4+2)^{2}=0,027<\mathrm{X}$ tabel $=3,84$, berarti H0 diterima

Pengetahuan tidak baik yang dimaksud adalah responden yang menjawab pertanyaan mengenai pengetahuan belum sempurna

Pengetahuan baik yang dimaksud adalah responden yang menjawab pertanyaan mengenai pengetahuan secara sempurna

Tabel 5 Perbandingan Sikap Responden mengenai Pemberian ASI Sebelum dan Sesudah Penyuluhan

\begin{tabular}{|c|c|c|c|c|}
\hline & \multicolumn{2}{|c|}{ Sesudah Penyuluhan } & \multirow[b]{2}{*}{ Jumlah } \\
\hline & & Sikap tidak baik & Sikap baik & \\
\hline \multirow{3}{*}{$\begin{array}{l}\text { Sebelum } \\
\text { Penyuluhan }\end{array}$} & $\begin{array}{l}\text { Sikap tidak } \\
\text { baik }\end{array}$ & 3 & 4 & 7 \\
\hline & Sikap baik & 4 & 14 & 18 \\
\hline & & 7 & 18 & 25 \\
\hline
\end{tabular}

Keterangan: Uji McNemar : X hitung $=(\mathrm{I} 4-4 \mathrm{I}-1)^{2} /(4+4)^{2}=0,015<\mathrm{X}$ tabel = 3,84, berarti H0 diterima

Sikap tidak baik yang dimaksud adalah responden yang menjawab pertanyaan mengenai sikap belum sempurna

Sikap baik yang dimaksud adalah responden yang menjawab pertanyaan mengenai sikap secara sempurna

\section{Tabel 6 Perbandingan Perilaku Responden Mengenai Pemberian ASI Sebelum dan} Sesudah Penyuluhan

\begin{tabular}{|c|c|c|c|c|}
\hline & \multicolumn{2}{|c|}{ Sesudah Penyuluhan } & \multirow[b]{2}{*}{ Jumlah } \\
\hline & & Perilaku tidak baik & Perilaku baik & \\
\hline \multirow{3}{*}{$\begin{array}{l}\text { Sebelum } \\
\text { Penyuluhan }\end{array}$} & $\begin{array}{c}\text { Perilaku tidak } \\
\text { baik }\end{array}$ & 3 & 4 & 7 \\
\hline & Perilaku baik & 4 & 14 & 18 \\
\hline & & 7 & 18 & 25 \\
\hline
\end{tabular}

Keterangan: Uji McNemar : X hitung $=(\mathrm{I} 4-4 \mathrm{I}-1)^{2} /(4+4)^{2}=0,015<\mathrm{X}$ tabel = 3,84, berarti H0 diterima

Perilaku tidak baik yang dimaksud adalah responden yang menjawab pertanyaan mengenai perilaku belum sempurna

Perilaku baik yang dimaksud adalah responden yang menjawab pertanyaan mengenai perilaku secara sempurna

\section{Diskusi}

Hasil penelitian ini menunjukkan bahwa pengetahuan responden mengenai ASI Eksklusif berpengaruh pada sikap dan perilaku responden tersebut. Penyuluhan-penyuluhan mengenai ASI Eksklusif dimaksudkan agar responden memiliki peningkatan pengetahuan tentang ASI Eksklusif untuk meningkatkan cakupan ASI Eksklusif, yang diharapkan dapat mengalami peningkatan di seluruh daerah di Indonesia. Hal ini akan sangat berpengaruh pada 


\section{Research Article}

kesehatan dan kecerdasan genarasi muda yang pada gilirannya akan berpengaruh pada kejayaan bangsa Indonesia.

Hasil menunjukkan pada umumnya pengetahuan, sikap, perilaku baik sebelum penyuluhan maupun sesudah penyuluhan ternyata cukup baik. Hal ini ditunjang dengan perhitungan statistik yang hasilnya tidak ada perbedaan baik pengetahuan, sikap, maupun perilaku responden sebelum dan sesudah penyuluhan mengenai pemberian ASI. Pengetahuan yang tidak baik tercantum pada tabel 4 yang dimaksud adalah responden yang tidak menjawab benar seluruh pertanyaan mengenai pengetahuan, responden tersebut memberikan jawaban salah pada satu atau dua pertanyaan saja. Hanya responden yang menjawab benar pada seluruh pertanyaan mengenai pengetahuan (10 buah) dikategorikan sebagai responden berpengetahuan baik. Pengertian yang sama berlaku untuk sikap yang baik pada tabel 5, juga untuk perilaku yang baik pada tabel 6 . Pengetahuan, sikap, dan perilaku responden sebelum penyuluhan tergolong sudah cukup baik walaupun memang belum menjawab seluruh pertanyaan dengan benar. Hasil penelitian menunjukkan terdapat faktor-faktor yang berpengaruh pada pemberian ASI eksklusif, selain penyuluhan mengenai pemberian ASI. Faktor-faktor lain yang berpengaruh antara lain dukungan keluarga, dan faktor ketersediaan ASI yang dipengaruhi gizi ibu menyusui. Responden yang menjawab pertanyaan "Bayi diberi ASI eksklusif sampai usia 6 bulan" ternyata baru mencapai 91-93\%, sehingga masih ada kemungkinan bayi usia 0-6 bulan tidak diberi ASI Eksklusif. Pernyataan responden yang menjawab pertanyaan "Ibu memberikan ASI saja kepada bayi sampai usia 6 bulan" sekitar 90-92\%, artinya belum 100\% paham bahwa pemberian ASI Eksklusif itu sangat penting bagi pertumbuhan dan perkembangan bayi, yang menunjang kesehatan baik ibu maupun bayinya. Uji statistik sebelum dan sesudah penyuluhan menunjukkan hasil berbeda tidak bermakna. Hal ini menandakan penyuluhan-penyuluhan yang didapat ibu sebelumnya cukup efektif bagi responden dalam menjawab pertanyaan sebelum dan sesudah penyuluhan. Beberapa poin jawaban responden sesudah penyuluhan menunjukkan penurunan sesudah penyuluhan. Hal ini disebabkan beberapa responden memiliki status belum menikah, ada juga yang usia responden 50 tahun atau mendekati 50 tahun. Responden yang memiliki status belum menikah belum memiliki pengalaman tentang pemberian ASI, sehingga bingung dalam memberi jawaban walaupun sudah diberi penyuluhan. Beberapa responden yang telah memasuki usia lanjut memberikan jawaban yang tidak benar setelah diberi penyuluhan. Hal ini diduga berhubungan dengan penurunan daya ingat dan juga penurunan kognisi, selain itu pengalaman memberikan ASI pada bayinya telah berselang sekian puluh tahun. Hasil kuesioner menunjukkan bahwa niat ibu untuk memberikan ASI Eksklusif dipengaruhi oleh informasi yang didapat dari berbagai 


\section{Research Article}

penyuluhan sebelumnya, dari media sosial, mengenai ASI eksklusif dengan demikian berbagai penyuluhan termasuk penyuluhan melalui media sosial perlu terus digalakan.

Pemberian ASI pada bayi sangat bermanfaat, terbukti pada bayi-bayi yang mendapat donor ASI. Donor ASI dalam hal ini diberikan pada bayi tersebut, karena ibunya tidak memungkinkan untuk menyusui langsung. Bayi yang mendapat ASI donor ini dibandingkan dengan yang tidak mendapat ASI terbukti menunjukkan efek positif yaitu tumbuh kembang yang baik, jarang terjadi diare, dan dermatitis atopik, serta penyakit infeksi oportunistik lainnya. ${ }^{8}$ Hal ini membuktikan bahwa pemberian ASI pada bayi sangat penting untuk dilakukan, dan oleh karenanya, perlu upaya penggalakan ASI dan pemberian ASI Eksklusif secara terus menerus. Upaya yang dapat diusahakan untuk meningkatkan cakupan ASI Eksklusif yaitu Inisiasi Menyusui Dini (IMD) dan kontak kulit-ke-kulit merupakan upaya yang mudah dilakukan dan efektif untuk IMD. ${ }^{9}$ Upaya meningkatkan cakupan ASI Eksklusif dapat pula dilakukan dengan program pelatihan khusus yang memang terbukti efektif. ${ }^{10}$

Penelitian oleh Nurleli (2017) menemukan bahwa pengetahuan ibu tentang ASI eksklusif memiliki hubungan signifikan dengan tindakan pemberian ASI eksklusif $(\mathrm{p}<0,05)$, di samping sikap juga memiliki hubungan signifikan dengan tindakan pemberian ASI eksklusif $(\mathrm{p}<0,05){ }^{11}$ Penelitian oleh Yanuarini (2017) menunjukkan bahwa terdapat hubungan antara pengetahuan dengan sikap ibu dalam pemberian ASI Eksklusif di wilayah kerja Puskesmas Pranggang Kabupaten Kediri. ${ }^{12}$ Sikap merupakan faktor terpenting yang mempengaruhi tercapainya pemberian ASI eksklusif. ${ }^{13}$ Upaya-upaya untuk meningkatkan pengetahuan ibu sangat diperlukan sehingga mempengaruhi sikap dan perilaku ibu yang merupakan hal yang penting dalam mencapai target cakupan pemberian ASI eksklusif.

\section{Simpulan}

Pengetahuan responden mengenai ASI Eksklusif sudah cukup baik, namun belum semua / belum 100\% responden yang memahami dan memiliki sikap serta memiliki perilaku untuk memberikan ASI Eksklusif pada bayinya.

\section{Ucapan Terima Kasih}

Terima kasih kepada Fakultas Kedokteran dan Lembaga Penelitian dan Pengabdian Masyarakat Universitas Kristen Maranatha, yang mendanai penelitian ini. Terima kasih juga kami tujukan kepada Ps. Ferry Sutrisna Widjaja, Ketua Yayasan Sahabat Lingkungan Hidup beserta 


\section{Research Article}

tim, yang telah membantu persiapan dan pelaksanaan penelitian ini. Terima kasih juga ditujukan kepada PT SOHO Global Health atas peran sertanya dalam mendukung penelitian ini.

\section{Daftar Pustaka}

1. Umboh, E. Wilar,R. Mantik, M.F. Pengetahuan Ibu Mengenai Manfaat ASI Pada Bayi. Jurnal e-Biomedik (eBM): 2013:1(1):210.

2. WHO, The World Health Organization's infant feeding recommendation. Cited $23^{\text {rd }}$ December 2020. Available at https://www.who.int/nutrition/topics/infantfeeding_recommendation/en/

3. Pusat Data dan Informasi Kementerian Kesehatan RI. Menyusui sebagai Dasar Kehidupan. 2018. Diunduh 20 Februari 2021 Tersedia dari https:/www.kemkes.go.id/article/view/19011500003/menyusui-sebagai-dasarkehidupan.html.

4. Badan Pusat Statistik. Profil Kesehatan Ibu dan Anak 2018. Jakarta. 2018

5. Anatolitou, F. Human Milk Benefits and Breastfeeding. J Pediatr Neonat Individualized Med 2012;1(1):11-8.

6. Purnamasari D. Mufdlilah. Factors Associated With Failure Of Exclusive Breastfeeding Practice. Journal of Health Technology Assessment in Midwifery. 2018;1(1):17-22.

7. Permatasari TAE. Sartika RAD, Achadi EL, Purwono U, Irawati AA. Ocviyanti D. et al. Exclusive Breastfeeding Intention among Pregnant Women. National Public Health Journal. 2018;12(3):134-41.

8. Reimers, P. Shenker, N. Weaver, G. Coutsoudis, A. Using Donor Human Milk To Feed Vulnerable Term Infants: A Case Series in KwaZulu Natal, South Africa. Int Breastfeeding J.; 2018;13(43):1-8.

9. Safari1, K. Saeed, A.A. Hasan, S.S. Lida Moghaddam-Banaem, L. The Effect Of Mother And Newborn Early Skin-To-Skin Contact On Initiation Of Breastfeeding, Newborn Temperature And Duration Of Third Stage Of Labor. Int Breastfeeding J.; 2018;13(32): 1-8.

10. Sullivan EM, Bignell WE, Andrianos A, Anderson AK. Impact Of Education And Training On Type Of Care Provided By Community-Based Breastfeeding Counselors: A Cross-Sectional Study. Int Breastfeeding J. 2011; $6(12): 1-13$.

11. Nurleli N, Purba JM, Sembiring R. Hubungan Pengetahuan dan Sikap Ibu Dengan Tindakan Pemberian ASI Eksklusif di Puskesmas Rambung Kecamatan Binjai Selatan Kota Binjai Tahun 2017. J Ris Hesti Medan Akper Kesdam I/BB Medan. 2018;3(1):1.

12. Yanuarini TA, Rahayu DE, Prahitasari E. Hubungan Pengetahuan dengan Sikap Ibu dalam Pemberian ASI Eksklusif di Wilayah Kerja Puskesmas Pranggang Kabupaten Kediri. J Ilmu Kesehat. 2017;3(1):1.

13. Prasetio TS, Permana OR, Sutisna A. Hubungan Pengetahuan, Sikap, dan Perilaku Ibu Tentang ASI dengan Keberhasilan ASI Eksklusif: Puskesmas Pancalang Kabupaten Kuningan. J Kedokt Kesehat Hub. 2020;6(1):1-6. 